Nuntius Antiquus, Belo Horizonte, v. 12, n. 1, p. 27-45, 2016

\title{
Há algo novo na Helena de Górgias?
}

\section{C’è qualcosa di nuovo nell'Elena di Gorgia?}

Stefania Giombini

Universidade de Girona

Girona, GI - Espanha

stefania.giombini@gmail.com

Tradutor: Ricardo Sontag

Resumo: O escopo deste artigo é investigar aspectos inéditos ou pouco considerados pela literatura crítica no Elogio de Helena de Górgias. Górgias foi um retórico capaz de análises filosóficas, e, graças à versatilidade do texto epidítico, entendido como um recipiente neutro para conteúdos que demonstrem a habilidade do sofista, nos transmitiu uma pluralidade de informações, exibindo amplas competências e conhecimentos em âmbitos muito diferentes. Entre os elementos presentes no Elogio, aqui serão analisados: a operação de desresponsabilização moral a favor de Helena, a presença de elementos de direito da época, a produção de uma definição similar a das escolas socrático-platônicas e uma primeira diferenciação em relação aos saberes antigos no caminho da especialização. No pequeno texto de Górgias, a personagem e a história de Helena desaparecem para dar espaço às argumentações lógicas e à grande habilidade retórica do sofista.

Palavras-chave: Górgias; Elogio de Helena; retórica; epidítica; direito grego antigo; definição.

Riassunto: Lo scopo di questo articolo è invetigare aspetti inediti, o tenuti in poca considerazione dalla letteratura critica, dell'Encomio di Elena di Gorgia. Gorgia è stato un retore capace di analisi filosofiche 
e, grazie alla versatilità del testo epidittico inteso come un contenitore neutro per l'immissione dei contenuti atti a mostrare l'abilità del sofista, ci ha trasmesso una pluralità di informazioni, dimostrando ampie competenze e conoscenze in ambiti anche molto diversi tra loro. Tra gli elementi presenti nell'Encomio, qui vengono analizzati: l'operazione di deresponsabilizzazione morale a favore di Elena, la presenza di elementi di diritto dell'epoca, la produzione di una definizione similare a quelle di scuola socratico-platonica e una prima differenzazione dei saperi antichi che cominciano a prendere la via della specializzazione. Nell'operetta di Gorgia, il personaggio e la storia di Elena spariscono per lasciare spazio alle argomentazioni logiche e alla grande abilità retorica del sofista.

Parole-chiave: Gorgia; Encomio di Elena; retorica; epidittica; diritto greco antico; definizione.

Artigo recebido em 13 de outubro de 2015 Aprovado para publicação em 8 de novembro de 2015

Há algo novo na Helena de Górgias? Fico tentada a responder a essa pergunta, que também intitula este meu artigo, dizendo: "não, não existe nada de novo a dizer sobre o Elogio de Helena de Górgias". Por outro lado, nos últimos anos, alternaram-se muitos estudos sobre a pequena obra, inclusive monografias encorpadas, numerosas comunicações em congressos e trabalhos da mais variada natureza e, então, tudo aquilo que poderia ser destrinchado parece já dito, seguro e à mão de qualquer estudioso.

Górgias, por séculos, foi obscurecido pela interpretação socráticoplatônica-aristotélica. De fato, a opinião negativa, a ideia de um sofista vão e que falava no vazio foi filtrada na construção doxográfica de Vidas de Filósofos, de Diógenes Laércio, e, depois, aportou às primeiras histórias da filosofia, desde aquela de Thomas Stanley de 1656 (1701) a de Jakob Brucker (1742). Esse monólito interpretativo foi lentamente desmontado ao longo do século XX e deste século, e é inegável que a tentativa de empreender uma "redescoberta" do sofista por parte de Leontini, objetivamente, teve sucesso. Sim, Górgias foi redescoberto!

Tal redescoberta aconteceu, também, graças à introdução dos seus textos (fragmentos e testemunhos) na coletânea de Diels-Kranz (1903) desde a terceira edição de 1912 (e já, em parte, na edição anterior 
de 1906-1910), mas a força propulsora para aquilo que podemos definir como uma verdadeira "reabilitação" do sofista envolveu todo o século XX, em particular a partir dos anos de 1950 e 60, em função dos primeiros estudos especializados, com um pico ulterior nos anos de 1980, graças, também, a dois congressos internacionais que aconteceram em Cerisy-la-Salle (CASSIN, 1986) e em Lentini-Catania (MONTONERI; ROMANO, 1985): de qualquer forma, na segunda parte do século, a sua inclusão no interior do pensamento filosófico tomou uma forma definitiva. Que Górgias, agora, faz parte da história da filosofia é um dado adquirido, e eu creio que isso foi possível, também, devido a estudiosos em particular que, no sofista, procuraram o filósofo; e me refiro, entre outros, a Mario Untersteiner (1967), a George. B. Kerferd (1981) e a Giuseppe Mazzara (pelo menos na primeira monografia, Gorgia ontologo e metafisico, 1982), que privilegiaram o aspecto filosófico do sofista em detrimento do retórico. Em suma, houve uma particular tendência em reivindicar o valor filosófico de Górgias com o custo de redimensionar o seu substrato retórico, ou pelo menos de colocar esse aspecto em uma posição secundária.

E foi frutífera essa inclusão? Eu diria que sim; diria que ela teve resultados substanciais. Ainda que, diante desse esforço intelectual coletivo e de grande porte, as pequenas obras de Górgias foram lidas de maneira quase unívoca e, na minha opinião, ficaram à margem notas significativas. Além disso, eu gostaria de declarar que ainda há algo a se dizer, algo que inesperadamente existe nessas obras, mas que resiste a se deixar identificar. Esses dados ainda a descobrir podem ser avaliados se aceitarmos plenamente a retoricidade de Górgias, e, assim, se procurarmos por entre as pregas da sua retórica.

Tentar reequilibrar a dimensão filosófica e a retórica, ou melhor, ver Górgias sob uma luz menos filosófica, poderia nos ajudar a redescobrir outras dimensões. Há que se fazer, portanto, uma operação inversa em relação àquela que foi feita até hoje: é necessário admitir que Górgias não é um filósofo e, sobretudo, não o é como nós sempre quisemos entender, sem cair, com isso, na tentação de liquidá-lo como um retórico cujos discursos não têm nada a acrescentar aos nossos conhecimentos - pelo menos àqueles sobre o século $\mathrm{V}-$, mas somente divertir-nos. Aquilo que entendemos por "ser um filósofo" é algo que tem relação com "praticar a profissão de filósofo", ou seja, tem um sentido profissionalizante, de pertencimento a uma categoria profissional. Em débito com Livio Rossetti 
(2010) por um estudo que considero fundamental, L'invenzione della filosofia, cheguei à convicção de que no século $\mathrm{V}$ não era concebida a ideia de "fazer filosofia" enquanto profissão. Devemos prestar contas com o fato de que o conceito de "filósofo" nesse século não existia tal qual nós sempre o entendemos. Esse é um ponto chave, e creio que ele é, também, a premissa para contextualizar o nosso Górgias. De fato, àquela época, a figura do filósofo não estava delineada; ela é posterior. Então, quando atribuímos a Górgias o título de "filósofo", o fazemos $a$ posteriori, segundo o nosso horizonte conceitual, o nosso paradigma interpretativo: mas Górgias nunca teria se chamado filósofo, nunca teria falado "eu pratico a profissão de filósofo" ou "eu sou um filósofo"; certamente teria dito ser um sapiente, um sophos, termo que continua lexicalmente amplo, omniclusivo. E seria assim para todos os outros pensadores do século V.

Então, Górgias é um retórico ou um filósofo? Creio que Górgias era um retórico, um sofista com uma capacidade forte, significativa para propor ideias, reflexões, conceitos que hoje nós podemos chamar de filosóficos porque alinhados com a atitude indagatória, crítica, especulativa, que é própria da busca filosófica.

Então, a minha ideia de partida, que é a premissa, mas também o êxito subentendido da minha pesquisa, é que, com Górgias, estamos diante de um retórico com a habilidade de refletir sobre questões que hoje reconhecemos como filosóficas. E, para fazer isso, o nosso sofista serviuse do instrumento textual que melhor lhe permitia essa possibilidade intelectual: o texto epidítico.

\section{Uma ideia epidítica}

Eu quis até aqui declarar a minha ideia "não puramente filosófica, mas totalmente epidítica" de Górgias (GIOMBINI, 2012, p. 47-53). Agora vou proceder à explicação do sentido dessa tomada de posição e

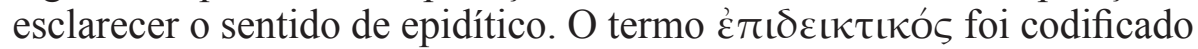
por Aristóteles na sua Retórica, enquanto antes ele não tinha assumido um significado definido e circunscrito. No livro I da Retórica, o Estagirita identifica, de fato, três gêneros para os discursos retóricos: o deliberativo, o judiciário e o epidítico. Para cada um deles Aristóteles se ocupa de delinear os seus objetivos e os seus temas. $O$ gênero deliberativo responde à exigência de guiar, sugerir, persuadir alguém a fazer ou não alguma 
ação que não segue um desenvolvimento natural, mas que depende do próprio sujeito e da sua vontade. Os temas em torno dos quais os homens são chamados a decidir são cinco para Aristóteles: as finanças, a guerra e a paz, a defesa do país, as importações e as exportações, e a legislação (Rhet. I 1357b18-21). O gênero judiciário é estritamente ligado à prática judiciária, à acusação e à defesa, e Aristóteles fornece a modalidade de construção desses discursos a partir da busca das motivações das ações (Rhet. I 1368b-1377b).

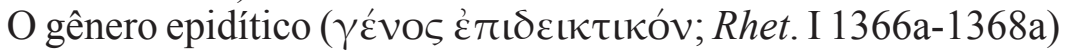
tem como objeto o elogio e a reprovação, e parece-me interessante notar que Aristóteles sublinha que existe uma diferença entre encômio e elogio (Rhet. I 1367b): o encômio refere-se a ações já realizadas por quem está sendo elogiado, enquanto o elogio é um discurso que evidencia a virtude do sujeito e a sua grandeza. Tal diferenciação, em Aristóteles, nos leva a refletir sobre a pequena obra de Górgias que, segundo o título, deveria se apresentar como um elogio das ações de Helena. E, como bem sabemos, foram exatamente as ações de Helena que fizeram dela uma mulher a ser condenada! Talvez Górgias quis ser paradoxal, desafiar o senso comum de modo absolutamente pessoal. Naturalmente trata-se de aplicar de maneira imprópria uma distinção aristotélica para um autor precedente, mas, pelo menos é estimulante produzir essa ligação. A definição de epidítico dada por Aristóteles é aquela que qualquer um de nós daria diante da pergunta: o que significa epidítico?

Em um texto sobre a história do elogio retórico, Laurent Pernot (1993, p. 25-42) se ocupou da natureza da epidítica antes de Aristóteles e chegou a uma conclusão com a qual concordo plenamente. De fato, sustenta o estudioso que, no termo "gênero epidítico", convivem dois aspectos: a $\varepsilon \operatorname{ci}^{\prime} \delta \varepsilon \iota \xi \xi \varsigma$ e a classificação dos gêneros. Por um lado, a

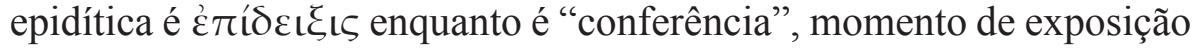
da habilidade do retórico: esse aspecto é, sem dúvida, vinculado à prática sofística com todas as suas especificidades. Por outro lado, é um gênero da retórica que Aristóteles distinguiu do deliberativo e do judiciário. Porém, e aqui está o ponto forte de Pernot, Aristóteles não esclareceu o sentido de epidítico, mas somente o restringiu, acabando por subdimensioná-lo. De fato, o Estagirita teria feito coincidir o gênero epidítico com o elogio, mas, como bem sublinhou o estudioso, a produção epidítica sofista é bem mais variada do ponto de vista do conteúdo do que o simples elogio. Por isso, seguindo esse raciocínio, não é possível classificar uma obra como 
epidítica pelo conteúdo, nem secundariamente pelo escopo - que nunca é de caráter prático, como nos discursos deliberativos ou judiciários -, mas exclusivamente pela forma.

Pernot estabeleceu muito bem, portanto, os limites da definição de Aristóteles, e isso nos facilita dizer que, por obras epidíticas, na época pré-aristotélica, é possível entender todas aquelas pequenas obras que eram eloquência de aparato com função celebrativa, com o objetivo de demonstrar a capacidade do retórico que propunha tais discursos para promover a sua imagem e o seu papel. Se entendermos ser necessário

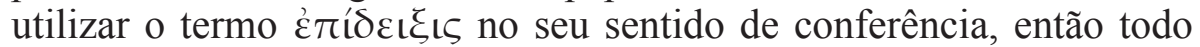
discurso - ou leitura pública - que não seja dicânico ou judiciário, nem deliberativo ou político, é epidítico, inclusive os discursos "sobre a tumba", sobre os "olímpicos", os textos paradoxais, aqueles com fins didáticos, os exercícios de composição e os textos realizados com fins "publicitários".

O texto epidítico é um "recipiente" no qual cada retórico coloca aquilo que sabe, aquilo que quer, aquilo que considera funcional à sua declamação, aquilo que lhe convém, aquilo que considera oportuno. Naturalmente, nesse vasto conjunto de $\lambda$ ó $\gamma O$ s epidíticos, é preciso efetuar as precípuas distinções em relação à natureza específica dos conteúdos desenvolvidos.

Voltando a Górgias, as pequenas obras do sofista, Elogio de Helena, Apologia de Palamedes e Epitáfio são, portanto, em sentido

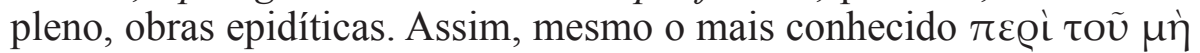

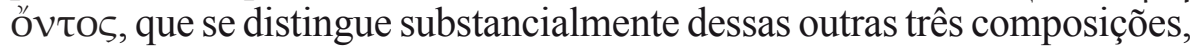
pelo fato de ser uma epidítica de "relevância", é destinada a um público especialista capaz de compreender as complexas argumentações de

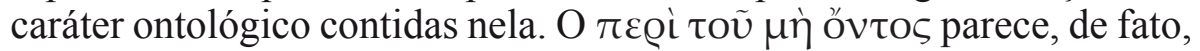
uma espécie de desafio ou uma provocação intelectual destinada aos especialistas em discursos "filosóficos", e não é assimilável no conteúdo a essa produção epidítica mais popular.

Qual é o escopo de Górgias? Muito simplesmente mostrar a própria capacidade e fazer publicidade de si mesmo. Evidenciá-la era necessário para quem tinha feito das suas capacidades uma fonte de renda, de resto uma renda generosa, como diversas fontes nos atestam. Quanto ao segundo ponto, fazer publicidade de si mesmo, ele está ligado não somente à leitura epidítica diante do público, mas também à difusão de pequenas obras que, no século $\mathrm{V}$, tinham um bom mercado 
editorial. Não se pensa muito nesse aspecto da cultura do século V, mas é certo que, ainda que não esteja atestada a presença de editores, os livros estavam entre os catálogos dos navios que chegavam e partiam de Atenas, e justo em Atenas existia um mercado de compra e de venda de livros (TURNER, 1977, p. 20-22). Logo, a difusão de pequenas obras epidíticas são um meio para o orador se fazer conhecer e apreciar; não se exclui que de Górgias já tinha sido lido algo em Atenas antes da sua chegada em 427 a.C.

Então, as obras epidíticas de Górgias nos parecem "recipientes" em que o retórico sofista colocava toda a sua capacidade, mostrava os seus conhecimentos, exibia os seus dotes argumentativos. E é por isso que eles nos parecem ainda mais como caixas de onde se tiram fragmentos para mostrar, para colocar em evidência.

De Górgias, como é sabido, restaram três obras inteiras (entre os sofistas, é o que restou mais): a Apologia de Palamedes, o $\pi \varepsilon \rho i$ toṽ

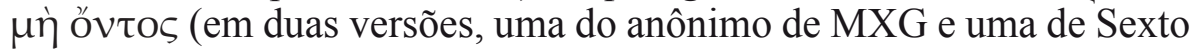
Empírico) e o Elogio de Helena; e, em maior número, fragmentos de orações, discursos e epitáfios.

Depois dessas premissas, aproximo-me gradualmente do Elogio de Helena, de Górgias.

\section{O Elogio de Helena: a datação e o título}

Gostaria de, rapidamente, dizer duas palavras sobre dois aspectos que podem parecer acessórios, mas, a meu ver, não o são. Primeiro, a datação da pequena obra, que nos diz algo não somente sobre o particular momento da sua produção, mas de todo um momento da "carreira" de Górgias.

Uma datação precisa de Helena não é possível, já que as fontes e os testemunhos antigos não dizem nada a propósito: os especialistas, seja do âmbito filológico, seja do filosófico, não puderam fazer outra coisa senão conjecturar, de maneira mais ou menos plausível, por meio de possíveis analogias com a obra de Antifonte, Acerca do assassinato de Herodes, e com as tragédias de Eurípides, Helena e Troianas. Mas, de fato, não existem indicações significativas a ponto de ser possível uma hipótese concreta (GIOMBINI, 2012). Eu creio que é mais fácil sustentar que o Elogio, assim como o Palamedes e o Epitáfio, foram escritos no ápice da carreira de Górgias, ou seja, no período posterior ao ano 427, 
quando, com a viagem a Atenas, o sofista atingiu a máxima notoriedade e vivia anos de objetiva fortuna. A pequena obra, portanto, é representativa da prática argumentativa e do estilo de Górgias, e é indicativa da produção ateniense de Górgias, aspecto relevante para alguns conteúdos da obra, como os jurídicos, que veremos mais adiante.

A outra questão, que não é propriamente secundária, a partir do momento que alguns estudiosos, inclusive atualmente, fundaram sobre ela partes das suas interpretações, é a natureza do título da obra, que parece não se conformar ao seu conteúdo. Como Isócrates (Hel. 14) já censurava em Górgias, o Elogio, mais do que um verdadeiro encômio (como, por sua vez, o próprio Isócrates se colocará a redigir), parece mais uma apologia. Isócrates tem razão ao dizer que a obra de Górgias parece uma apologia: de fato, grande parte do texto ocupa-se da defesa que o retórico faz da mulher, enquanto o encômio é limitado a dois parágrafos na parte inicial.

E, então, por que encômio? Mazzara (1999, p. 182 ss.) escreveu que o encômio, para ser tal, supõe uma apologia, e isso fez, sim, com que a parte dedicada à defesa fosse mais ampla do que aquela destinada ao elogio. Além disso, não se pode elogiar sem primeiro isentar da culpa. A ideia é iluminadora, mas também pode ser subvertida no seguinte sentido: não existindo as condições para levar a cabo uma formal apologia, é possível recorrer à via privilegiada do encômio. É preciso considerar que, muito embora Helena de Tróia tenha sido muito criticada, considerada culpada e tomada como modelo negativo, nunca houve um processo contra ela, e, ao contrário, depois da sua fuga, foi perdoada pelo marido Menelau que a acolheu na sua casa. Que não se trata de uma apologia escrita para um tribunal é evidente: não somente inexistiu um julgamento contra Helena, mas, é claro, inclusive na obra de Górgias, que não há qualquer tribunal, senão aquele da moral do público (a obra escrita, também, em terceira pessoa). Esse elemento não torna o episódio de Helena um caso judiciário, como é, ao contrário, o de Palamedes e, portanto, a rigor, não existem os pressupostos para a escrita de uma apologia.

Há, porém, material para construir um elogio a ser contraposto à culpa e à tendência geral ao juízo negativo. Assim, chamando o discurso sobre Helena de "encômio", Górgias não traiu o conteúdo (afinal, existe o encômio), mas, também, não explicitou a sua natureza apologética, que permanece implícita. Existem, portanto, os elementos para admitir que o 
termo encômio não é equivocado ou fora de lugar, mas, ao contrário, é apropriado. Há, ainda, a significativa presença do termo $\dot{\varepsilon} \gamma \kappa \omega \dot{\mu} \mu \mathrm{L}$ (§ 21) no fechamento da obra, que legitima o título para além da correspondência com o conteúdo do discurso.

\section{Vamos à obra...}

A obra é composta por 21 parágrafos: os dois primeiros dão lugar ao proêmio; do $\S 3$ ao $\S 5$ há o encômio em sentido estrito; do $\S 6$ ao $\S 20$ a argumentação da defesa; noß 21 o epílogo.

Depois do proêmio e do encômio em sentido estrito da figura de Helena, na parte que vai do $\S 6$ ao $\S 19$ desenrola-se a verdadeira argumentação a favor da inocência de sua inocência. Górgias inicia com a apresentação sumária das possíveis razões que poderiam explicar a fuga de Helena de Esparta. As motivações propostas pelo orador são quatro: Helena fez o que fez, ou por vontade divina (ou, de qualquer forma, pelo acaso ou pela Necessidade, ambos de natureza divina), ou por um ato de força sobre ela, ou porque foi persuadida pelas palavras, ou porque se apaixonou.

No interior dessas argumentações, vejamos alguns elementos relevantes.

\section{A desresponsabilização segundo a razão}

Na mitologia, Helena aparece como uma mulher fatal, portadora de desventuras, mas Górgias vai delinear um novo tipo de mulher, contando outra história. A primeira novidade do seu procedimento consiste em apontar as possibilidades concretas da ação de Helena (que resistem ao exame lógico-racional), mas também na própria articulação do discurso construído como um sistema inédito. A pequena obra se desenvolve, de fato, sobre quatro diretrizes constituídas pelas possíveis motivações de Helena e termina com o reclame de Górgias pela necessidade de inocentar a mulher. De fato, sustenta o sofista, ainda que não se possa saber o que aconteceu entre Helena e Parides, uma coisa é possível afirmar, com certeza: Helena é inocente porque qualquer força que a tenha movido a agir de determinado modo não podia ser evitada por ela. Essa conclusão não é uma tomada de posição, uma petitio principii, mas é uma conclusão racional: Górgias reabilita 
Helena, raciocinando sobre os motivos efetivos que uma mulher podia ter para deixar o próprio marido e os filhos, e seguir outro homem. Com isso, um corolário emerge de maneira inusitada: Helena não é responsável pelas suas ações, e a sua irresponsabilidade não é, absolutamente, um caso isolado. $\mathrm{O}$ caso individual revela-se dotado de um valor comumente plausível, senão inteiramente universal, porque estamos diante de um raciocínio logicamente construído que, em virtude da lógica, pode ser

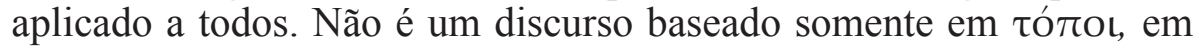
fórmulas ou argumentos pré-constituídos: estamos frente a uma análise racional das ações de Helena.

Olhemos somente a primeira razão proposta pelo o sofista. $\mathrm{Na}$ primeira motivação, Górgias se pergunta se Helena pode ter partido de Troia por vontade divina, por acaso, ou por Necessidade: se assim foi, Helena não pode ser considerada culpada, já que, segundo Górgias, é natural, ou seja, está na ordem das coisas, que o inferior seja vencido e condicionado pelo superior, e que, portanto, o superior guie e o inferior siga, e não o contrário. Ora, um deus é mais poderoso do que um homem: consequentemente, é mais forte do que Helena e pode determinar as suas ações. Se o deus quer que seja feita determinada ação, o culpado, se há culpa, será do próprio deus que quis aquela determinada ação, que quis dar um determinado curso aos eventos, enquanto a pessoa interessada limitou-se a sofrer, a seu malgrado, aquilo que não quis. A intervenção do deus leva a não-responsabilidade de Helena pelas ações realizadas, e, mesmo que haja, não é possível saber o quão instrumental foi o uso da desresponsabilização na Helena; o certo é que Górgias demonstra se mover, ao menos aqui, no interior da consciência e do saber comum, assim como fez em relação à teoria segundo a qual o mais forte vence o mais fraco, suspendendo, dessa forma, o próprio princípio sofístico que diz que o fraco tem a possibilidade de prevalecer sobre o mais forte. Efetivamente, a regra expressa nessa primeira motivação ajusta-se mal ao esquema do

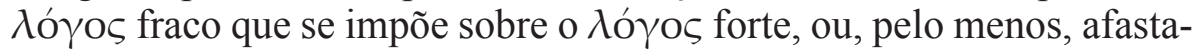
se dele de maneira significativa. A cultura da desresponsabilização é amplamente atestada no período clássico e antes de Górgias: de fato, culpar os deuses é um "velho modo" de defender Helena, cujos traços são possíveis de encontrar, não somente em Homero (Il. III 164), para o qual Príamo reconheceu como culpados os deuses e não Helena, mas também em Píndaro (O. 12. 1-2), em Sófocles (Ant. 1158), em Menandro (Aspis 147-148) e em Demóstenes (Ep. 2.5), segundo os quais foi decisiva 
a intervenção do acaso. O raciocínio desresponsabilizador, então, não é um caso anômalo, mas faz parte de uma postura comum no homem grego, que invocava frequentemente intervenções sobre-humanas para motivar as próprias ações. Mas a novidade de Górgias está em fazer disso um argumento: em torná-lo uma prova lógica capaz de resistir a qualquer objeção. Além disso, tal argumentação torna-se o modelo das provas subsequentes: de fato, a desresponsabilização é levada a cabo por Górgias também nas três possibilidades seguintes que seguem a linha da primeira, do ponto de vista da argumentação, e que têm o mesmo objetivo de declarar a não responsabilidade de Helena. Górgias tem essa capacidade de renovar os conceitos, de propô-los sob uma nova veste: de atualizá-los e de reforçá-los à luz de uma nova força argumentativa.

\section{Elementos de direito no Elogio de Helena}

Analisando argumentos mais específicos, eu me debruçarei no $\S 7$, no qual Górgias propõe a segunda motivação da fuga de Helena: a hipótese alternativa da intervenção violenta da parte do homem, o rapto. Com tal motivação, se, por um lado, muda significativamente a dinâmica dos eventos, por outro, é reproduzida a não culpabilidade da heroína. Se, de fato, Helena foi para Tróia porque foi raptada e, portanto, levada até lá com violência, não só não cometeu qualquer injustiça, como também foi ultrajada e, pelo que sofreu, foi desventurada. É preciso, portanto, reabilitá-la e ter piedade dela por ter sido uma vítima. Aqui se encontra um elemento que passou inobservado pela literatura crítica: o saber jurídico que Górgias exprime. De fato, sustenta o orador, é necessário que o raptor seja condenado, seja pela lei com a privação dos direitos de cidadão, seja pelos outros com o reconhecimento da acusação, e, portanto, que ele seja punido com uma pena pela deplorável ação que cometeu; por um lado, sofrerá a privação dos próprios direitos, e, por outro, deverá responder à acusação no tribunal. Isso porque o raptor violou não somente os seus deveres em relação à família dela, mas também em relação a toda a comunidade. Consequentemente, ele deve não somente ressarcir civilmente o marido e a família com uma multa, mas também ressarcir penalmente toda a cidade com a privação dos seus direitos de cidadão

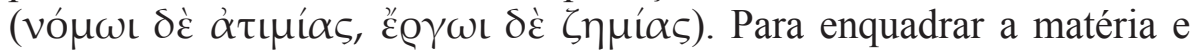
compreender em que contexto inserir essas notas de Górgias, é preciso entrar na ordem de ideias segundo a qual, no século V, o direito ainda é 
matéria in fieri e que não temos à disposição uma verdadeira literatura jurídica para confiar a tarefa de se tornar a nossa fonte para o assunto (entre tantos, por exemplo, BISCARDI 1982, p. 17 ss.). Nós dispomos somente de inscrições e $\psi \eta \varphi i ́ \sigma \mu \alpha \tau \alpha$, e de uma série de elementos jurídicos evocados em textos de outra natureza (quase totalmente epidítica), como as Tetralogias de Antifonte, que não são consideradas sempre confiáveis quanto à veridicidade e à correspondência real com o status da lei. Porém, é inegável que, aqui, Górgias evoca noções bem conhecidas no mundo ateniense. Creio que é particularmente relevante o resultado de um estudo de Livio Rossetti (1994, p. 3-26) sobre o aspecto penal e civil das Leis de Platão: Rossetti estabeleceu relações entre a obra de Platão e o pensamento de Hipódamo de Mileto, para, depois, instituir um vínculo entre este último e Górgias, especialmente em relação a Palamedes, também muito rico em sugestões de caráter judiciário. Para Rossetti, Hipódamo antecipou algumas instâncias platônicas e, sobretudo, o estudioso enfatizou os vínculos entre a ideia de suspender o juízo na espera por provas, o estabelecimento da custódia cautelar, a busca por provas mais consistentes que aparecem em Palamedes no $\S 16$, e o sistema elaborado por Hipódamo. Ele divide as leis em três tipos correspondentes às três matérias sobre as quais recaem as causas: ultraje, homicídio, dano. Existe, portanto, na sua perspectiva, uma primeira tomada de consciência sobre a necessidade de adaptar a legislatura ao crime segundo a sua tipologia. É possível, facilmente, identificar a proximidade entre essa última divisão de Milésio e a distinção que Górgias propõe neste parágrafo entre a culpa cometida e a pena que corresponde a ela, levando a cabo, dessa forma, uma diferenciação entre as responsabilidades em relação às ações e propondo a duplicidade da sanção penal. A conclusão de Rossetti, que valia para o Palamedes, parece ulteriormente valorizada por essa passagem de Helena: Górgias parece ter tomado de empréstimo essas noções de Hipódamo, mas não só: essa passagem mostra, junto com outros elementos que se encontram nas outras pequenas obras de Górgias, uma refinada sensibilidade para o direito que investia não somente os seus interesses pessoais, mas também a sua atividade de sofista. Um elemento ulterior que é possível aproximar à mesma discussão jurídica está presente, sempre em Helena, na introdução à terceira prova; no $\S 12$ Górgias levanta a hipótese segundo a qual se o que persuadiu Helena foi a palavra, apropriando-se das faculdades racionais da mulher, mesmo nesse caso não será difícil demonstrar a sua inocência. De fato, a palavra é caracterizada por um 


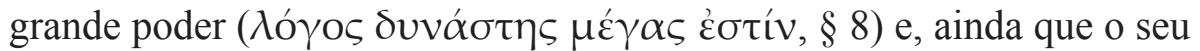
corpo seja muito pequeno, ela tem a possibilidade de intervir de maneira direta sobre os sentimentos: pode fazer cessar o medo, acabar com a dor, produzir alegria e aumentar a capacidade de sentir compaixão. No início do parágrafo, Górgias afirma que, se foi o discurso que convenceu Helena, então demonstrar a sua inocência não será difícil. Os $\lambda o ́ \gamma o \iota$ são capazes de provocar coisas inimagináveis; a potência deles é muito

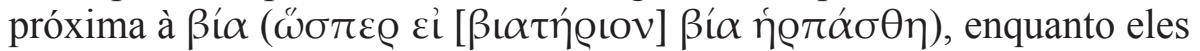
se configuram como capazes de produzir um consenso, mas tal consenso tem um aspecto "não consensual" e se torna um ato de força, justo porque resistir se torna impossível, ou quase. É plausível falar, portanto,

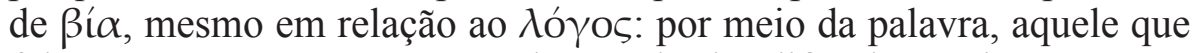
fala propõe uma representação do mundo simplificada e cativante, que o ouvinte facilmente a torna sua, chegando a olhar a realidade de um novo ponto de vista. Górgias levanta, aqui, uma eventualidade que não tinha sido antes levada em consideração por nenhum autor do passado e que não está presente nem em Platão. A palavra e o discurso são considerados verdadeiras armas de possível coerção, cuja potência pode, todavia, ser limitada. No momento em que, de fato, a palavra é mal utilizada, é possível disparar uma acusação de culpabilidade: o culpado deve assumir a responsabilidade pela ação que suscitou com as suas palavras. No caso específico, Parides é injusto, porque, com os seus discursos, conseguiu influenciar a opinião da mulher que foi, então, levada ao erro e a fugir

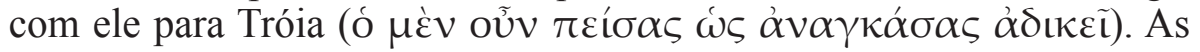
palavras tinham o poder de determinar as suas escolhas e, portanto, a responsabilidade por tais escolhas deslocava-se de quem cometeu a ação

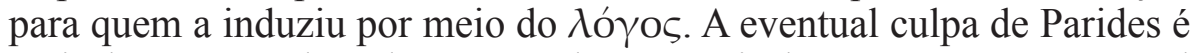
mais do que uma desculpa para Helena; é mais do que tornar responsável uma divindade, porque um culpado é encontrado, a sua arma é levada em consideração e são extraídas as consequências disso. Quando é possível identificar a culpabilidade em quem comunica? A culpabilidade subsiste se a comunicação acabou por produzir uma forma de constrição (ainda que tenha chegado somente à calúnia). Górgias não dá indicações ulteriores sobre o desenvolvimento desse reconhecimento da culpa, e, então, não são abordados elementos judiciários precisos, mas, sem dúvida, revela-se, mais uma vez, a sensibilidade do sofista em relação ao direito. 


\section{A definição}

No $\S 9$, Górgias, enquanto discute o poder do $\lambda$ ó $\gamma 0 \varsigma$, fornece um dos primeiros exemplos de definição da literatura e da filosofia antigas. O sofista começa afirmando que a poesia é, em geral, um discurso metrificado que provoca no ouvinte efeitos fortíssimos: é possível ser tomado por arrepios de terror ou por compaixão lacrimejante, ou por um desejo de chorar (de resto, o elenco desses efeitos é similar ao que Aristóteles atribui à tragédia na sua Poética, 1449b24-28), e a alma, quando exposta à força do $\lambda o ́ \gamma o \zeta$ que fala de pessoas e experiências fortunadas ou desfortunadas, sofre e é acometida por afeições. No início da passagem em exame, emerge a definição de poesia como discurso

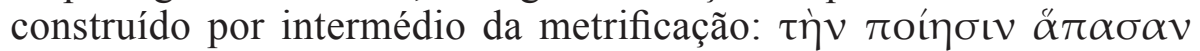

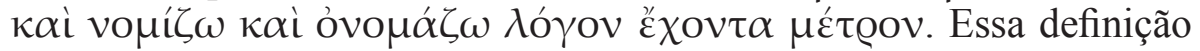
é um exemplo da produção da ars definiendi, viva no século $\mathrm{V}$, e é a primeira de que se tem notícia. Além disso, trata-se de uma definição tecnicamente bem feita: é breve, consegue identificar uma peculiaridade comum de qualquer composição poética, e, particularmente, somente das composições poéticas; então, evidencia um traço identitário, uma característica efetiva capaz de funcionar como critério para dizer se certo texto é ou não poético, se pode ou não ser considerado como tal: a definição breve, certamente, não pretende identificar a essência daquilo que é definido, mas identifica e localiza aquilo a que se refere.

Como se sabe, algumas tentativas de definição, mais ou menos felizes, emergem nos diálogos aporéticos de Platão, como no caso da arte poética como um todo no Ion (532c) ou do Górgias platônico (502c), em que Sócrates afirma que se fosse tirada da poesia a música, o ritmo e a metrificação restariam somente puros discursos. Aristóteles informa na Metafísica (1078b19) que, antes de Platão, inclusive Demócrito deu a definição de calor e de frio e se ocupou de definir o critério para chegar a estabelecer a essência (quididade) (BRAVO, 1985, p. 21). Mas, enquanto não conhecermos o texto da definição proposta por Demócrito, aqui, com Górgias, temos uma definição "modelo", formalmente muito próxima da definição socrático-platônica de óotótᄁৎ do Eutifron ("santo é aquilo que agrada aos deuses", 6e-7a). Relevar que Górgias pôde dar o exemplo desta nova ars definiendi faz nascer uma dúvida: tratar-se-á de uma invenção própria do século $\mathrm{V}$ e não, como sempre se acreditou, de uma herança platônica (ou socrático-platônica)? Ou poderia ser uma 
provocação à escola socrático-patônica, já que Górgias se apropria de uma metodologia de pesquisa que a caracteriza? Não existem, naturalmente, as condições para uma resposta, mas há de ser registrada, pelo menos, a legitimidade das perguntas. Alternativamente, seria possível enxergar na passagem uma manifestação de competências acidentais, deixado à admiração tácita dos leitores e empregado para satisfazer aqueles mais exigentes acerca do profissionalismo do autor. Essa explicação tem a vantagem de ser, como se diz, mais econômica, ainda que não se possa descartar um contraste, mais ou menos veladamente irônico, levado a cabo por Górgias em relação a Platão.

\section{Um saber em construção}

Vamos ao último elemento que pretendo colocar hoje em foco. Depois do enunciado do final do $\S 12$, em que se encontra a ideia da capacidade coercitiva dos $\lambda$ ó $\gamma \mathrm{ol}$, Górgias constrói, no $\S 13$, um discurso de grande fôlego, reportando exemplos sobre como e quando advém o condicionamento sobre a opinião. Esses exemplos são antecipados por um inciso breve, mas muito significativo: Górgias afirma que se servirá dos casos elencados na sequência para demonstrar como a persuasão consegue agir sobre a alma, e identifica três tipologias de discurso: o discurso dos metereólogos, o discurso filosófico e o discurso

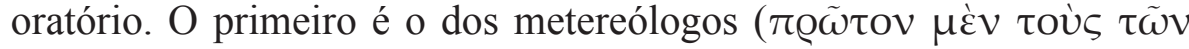

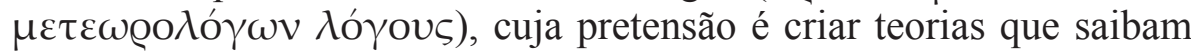
dar conta dos fenômenos naturais. Mas eles constroem e demolem teorias modificando as hipóteses, que não podem ser comprovadas por ninguém, porque, pretendendo tornar manifesto aquilo que é obscuro, fazem acreditar à maioria aquilo que é inacreditável e invisível. A crítica aos físicos, então, é a de esconder sob o objetivo de explicar os fenômenos uma ciência não exata, que muda incessantemente e que se constitui por meio de discursos que, no momento, têm a pretensão de exaustividade, mas mudam continuamente e fazem mudar as opiniões daqueles que acreditam nelas. Então, o saber deles parece sólido, mas não

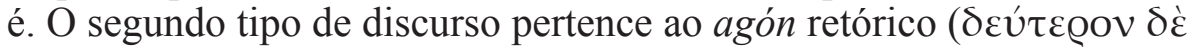

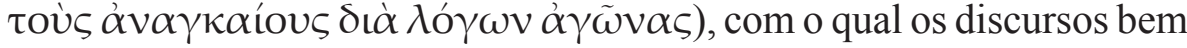
construídos conseguem persuadir grandes multidões. A crítica consiste em relevar que tais discursos, ainda que capazes de divertir e persuadir, estão baseados na arte que os produziu, e não na verdade. 
O último exemplo se concentra nas disputas filosóficas ( $\tau$ @ítov

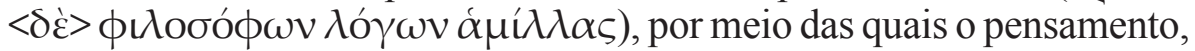
que se desdobra em raciocínios velozes, pode conduzir a fáceis mudanças de opinião. As disputas filosóficas podem ser aproximadas a todos os outros componentes retóricos; eles, de fato, não somente produzem opiniões mutáveis, e isso pressupõe a não aderência delas (ou uma aderência não reconhecida) à realidade, mas são caracterizadas, além disso, pela velocidade. Esses discursos filosóficos são chamados em causa com acepção negativa e resulta fácil pensar que, aqui, Górgias pretende atacar alguns sábios dos quais conhecia bem as argumentações de tipo filosófica. Poderia se tratar daquele âmbito da investigação filosófica

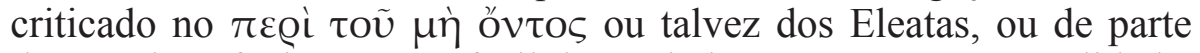
do mundo sofístico. Não é fácil de estabelecer quem são, na realidade, aqueles que produzem discursos filosóficos, visto que não dispomos de outras informações.

Em geral, as três tipologias de discurso identificadas por Górgias são submetidas à crítica, e os saberes que elas representam são apresentados como débeis, fugazes e não verdadeiros. É necessário

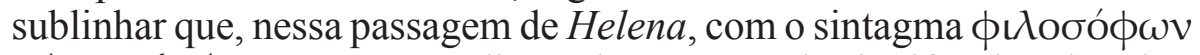
$\lambda o ́ \gamma \omega \nu \alpha \dot{\alpha} i \lambda \lambda \alpha \varsigma$, estamos diante de um atestado significativo do saber filosófico in fieri. As notícias mais antigas nos dizem que o primeiro a ter se definido como filósofo foi Pitágoras. A informação teria sido transmitida por um discípulo de Platão, Heráclides do Ponto. Essa indicação nos foi dada por Cícero (Tusc. V 3.7-9), que afirma claramente que Pitágoras se denominava filósofo e não somente sapiente (artem quidem se scire nullam, sed esse philosophum). A distinção parece ter certo valor, na medida em que parece querer nos transmitir a vontade de Pitágoras de não ser somente um sapiente, mas de ter uma propensão a filosofar a ponto de ter que ser definido como filósofo. Outro dado a esse propósito está presente no Proemio de Vidas de Filósofos, de Diógenes Laércio $(\mathrm{I}, 12)$, em que se lê que Pitágoras usou pela primeira vez o termo

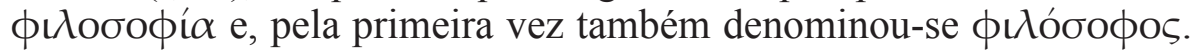
Mas o quão válidas são essas fontes do discípulo de Platão, Heráclides do Ponto? Não muito, de acordo com o que sustentou W. Burkert (1960),

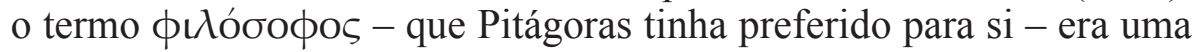
invenção de Platão, retomada e transmitida por Heráclides do Ponto; logo, não seria realmente de Pitágoras. Então, segundo Burkert, no período

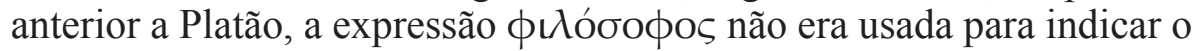


especialista da filosofia, tanto que se pode encontrá-la somente em outras acepções mais amplas e genéricas. Existem, ainda, duas citações muito

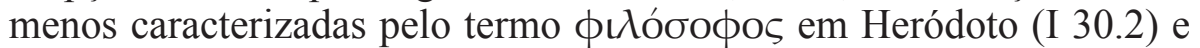
em Heráclito (22B35). Aqui, o sentido é o genérico de "fazer filosofia", cultivar o saber sem polarizar-se em um tipo particular, que é possível encontrar, também, em outros autores, como, por exemplo, Tucídides (2.40). Talvez, em um sentido menos genérico, encontramos a presença

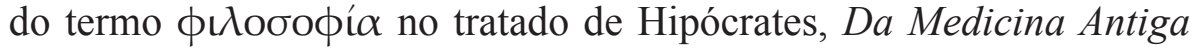
(20). Aqui, ele é diretamente atribuído a Empedócles e a outros autores semelhantes, e, portanto, é entendido como "filosofia da natureza", assumindo um significado menos abrangente; o autor não o discute mais amplamente e compreender bem a sua dimensão para os fins da nossa pesquisa acaba sendo difícil. Então, a especialização da filosofia como disciplina autônoma, com um estatuto próprio, praticada por quem se reconhece como filósofo em sentido estrito, foi uma consciência tardia da filosofia que, antes, caracterizava-se muito mais como um saber genérico e aberto, não setorial e em busca das próprias fronteiras, como eu pude sustentar no início deste discurso. Em geral, aqui no $\S 13$, Górgias delineia uma ruptura da cultura da época e, ainda que muitas coisas tenham sido somente acenadas, trata-se de um olhar sobre formas de saber que, no século V, vão se consolidando e constituindo o seu estatuto específico.

\section{E, então...}

A ideia que eu espero ter apresentado, aqui, é a de um Górgias ainda a explorar e, com isso, ainda a ser compreendido. Existem muitos dados que ficaram sem atenção por um longo tempo que podem nos ajudar a definir de maneira nova Górgias e a sua produção, e que nos permitem sair definitivamente do impasse historiográfico, do bloco epistêmico que circunscreveu forçosamente a nossa ideia do sofista. Eu creio que é necessário partir da ideia do recipiente epidítico para entrar paulatinamente nos particulares, sem nunca cair na tentação de "grudar" etiquetas historiográficas onde não é necessário. No fim das contas, Górgias nos apresenta uma nova Helena, uma mulher diferente daquela transmitida pelo mito e aceita pelo sentir comum: na obra do sofista, a tradicional Helena desaparece, dando lugar ao raciocínio e à retórica. 
*Registro um agradecimento ao Prof. Dr. Ricardo Sontag (Direito/ UFMG), que se ocupou com grande atenção e cuidado da tradução deste texto do italiano para o português. Aproveito a ocasião para agradecer ao grupo de Filosofia Antiga da UFMG, e, em particular, à Maria Cecília de Miranda Nogueira Coelho, por ter me convidado para o VI Simpósio Lendo, Vendo e Ouvindo o Passado: Eros e Helena, de Troia a Vila Rica, para o qual a primeira versão deste texto foi preparada, e que foi uma magnífica ocasião para trocas intelectuais e inesperadas amizades.

\section{Referências}

BISCARDI, A. Diritto Greco Antico. Milano: Giuffrè Editore, 1982.

BRAVO, F. Teoría Platónica de la Definición. Caracas: Editorial Facultad de Humanidades y Educación-UCV, 1985.

BRUCKER, J. J. Historia critica philosophiae. Lipsiae: Bern. Christoph. Breitkopf, 1742.

BURKERT, W. Platon oder Pythagoras? Zum Ursprung der Wortes Philosophie. Hermes, Stuttgart, v. LXXXVIII, p. 159-177, 1960.

CASSIN, B. (Ed.). Positions de la Sophistique. Colloque de Cerisy. Paris: Vrin, 1986.

DIELS, H.; KRANZ, W. Die Fragmente der Vorsokratiker. Berlin: Weidmannsche Buchhandlung, 1903 (1912³).

GIOMBINI, S. Gorgia epidittico. Commento filosofico all'Encomio di Elena, all'A pologia di Palamede, all'Epitaffio. Perugia: AguaplanoOfficina del Libro, 2012.

KERFERD, G. B. The Sophistic Movement. Cambridge: Cambridge University Press, 1981.

MAZZARA, G. Gorgia ontologo e metafisico. Palermo: Ila Palma, 1982.

MAZZARA, G. Gorgia. La retorica del verosimile. Sankt Augustin: Academia Verlag, 1999.

MONTONERI, L.; ROMANO, F. (Ed.). Gorgia e la sofistica. Atti del Convegno Internazionale (Lentini-Catania 12-15 dic. 1983). Catania: Univ. di Catania, Fac. di Lettere e Filosofia 1985, Siculorum Gymnasium, v. XXXVIII, 1985. 
PERNOT, L. La rhétorique de l'éloge dans le monde gréco-romain. Paris: Institut d'Etudes Augustiniennes, 1993.

ROSSETTI, L. Processo e istituzioni giudiziarie nelle Leggi di Platone. In: GIULIANI, A.; PICARDI, N. (Ed.). L'educazione giuridica VI: Modelli storici della procedura continentale. Profili filosofici, logici, istituzionali I. Napoli: Edizioni Scientifiche Italiane, 1994.

ROSSETTI, L. L'invenzione della filosofia. Bollettino della Società Filosofica Italiana, Roma, vol. n.s. 200, p. 3-16, mag./ago. 2010.

STANLEY, Th. A history of philosophy. London: Battersby at Thavi's inn-gate 1701 .

TURNER, E.G. I libri nell'Atene del V e IV secolo. In: CAVALLO, G. (Ed.). Libri, editori e pubblico nel mondo antico. Guida storica e critica. Roma - Bari: Laterza, 1977 (1975). p. 5-24.

UNTERSTEINER, M. I Sofisti. Milano: Bruno Mondadori, 1967. 
